\title{
Forest structure and regeneration responses 15 years after wildfire in a ponderosa pine and mixed-conifer ecotone, Arizona, USA
}

Michael T Stoddard ${ }^{1 *}$ (D) David W Huffman ${ }^{1}$, Peter Z Fulé2 ${ }^{2}$ Joseph E Crouse ${ }^{1}$ and Andrew J Sánchez Meador ${ }^{1,2}$

\begin{abstract}
Background: Accelerated vegetation changes are predicted for Southwestern forests due to changing disturbance regimes and climate. The 2001 Leroux Fire burned across a landscape with pre-existing permanent plots during one of the most extreme drought periods over the last few decades, providing a rare opportunity to assess wildfire -drought interactions. The wildfire burned with variable severity across a mountainous transition zone. We took advantage of this opportunity to re-measure plots originally established in 2000, and extend the temporal scale of response data to 15 years post-fire.

Results: Although fire severity classification adequately described initial effects, tree mortality was indistinguishable among the burned plots between 2002 and 2016, ranging from 38 to 41\%. Our results indicated extensive secondary tree mortality that nearly equaled initial mortality in three of four fire severity classes. Mortality from 2002 to 2016 varied by species, with quaking aspen (Populus tremuloides Michx.) experiencing disproportionately higher mortality (46 to $62 \%$ tree loss) than other species across all fire severities. Ponderosa pine (Pinus ponderosa Engelm.) mortality (34\% tree loss) between 2002 and 2016 on unburned plots, along with similar mortality on moderate- and high-severity plots, show that even the most drought-tolerant species on our site was affected by exceptionally warm and dry conditions. Regeneration immediately post fire was dominated by aspen sprouts across all fire severities. By 2016, however, aspen densities were lower than pre-fire observations in unburned, moderate- and high-severity plots, and conifer seedlings primarily established in unburned plots. Ponderosa pine seedlings established between 2011 and 2016 and were observed in only one unburned plot in 2016. The lack of pine regeneration and the relatively small size of high-severity patches in the Leroux Fire suggest that factors other than seed dispersal limited ponderosa pine regeneration.

Conclusions: Substantial mortality (68\% tree loss) and 39\% basal area reduction over the 15-year study, plus variable aspen regeneration and sparse conifer regeneration, led to non-forested conditions and isolated aspen stands. Although small in size, the Leroux Fire provided an example of continuing post-fire forest community changes driven by temperature increases and drought. Thus, wildfire and climate change interactions may accelerate shifts in structure and composition in Southwest forest ecosystems.
\end{abstract}

Keywords: burn severity, drought, ecotone, extended tree mortality, regeneration

\footnotetext{
* Correspondence: mike.stoddard@nau.edu

'Northern Arizona University, Ecological Restoration Institute, P.O. Box 15017,

Flagstaff, Arizona 86011, USA

Full list of author information is available at the end of the article
} 


\section{Resumen}

Antecedentes: Cambios acelerados en la vegetación se pronostican para los bosques del sudoeste de los EEUU debido a modificaciones en los regímenes de disturbios y en el clima. El Incendio de Leroux de 2001 quemó durante uno de los períodos de sequía más extremos en las últimas décadas, un paisaje con parcelas permanente preexistentes, lo que proporcionó una rara oportunidad para determinar las interacciones entre incendios y sequía. El incendio quemó con severidad variable a través de una zona montañosa de transición. Sacamos provecho de esta oportunidad para remedir las parcelas originalmente establecidas en 2000 y extendimos la escala temporal de datos-respuesta 15 años post-incendio.

Resultados: Aunque la clasificación de la severidad del fuego describió adecuadamente sus efectos iniciales, la mortalidad de los árboles fue indistinguible entre las parcelas quemadas entre 2002 y 2016, cuyo rango fue del 38 al $41 \%$. Nuestros resultados indicaron una mortalidad secundaria más extendida que casi igualó la mortalidad inicial en tres de las cuatro clases de severidad. La mortalidad desde 2002 a 2016 varió entre especies, con el álamo temblón (Populus tremuloides Michx.) mostrando una mortalidad desproporcionada (46 a $62 \%$ de árboles muertos) comparada con otras especies y a través de todas las severidades. La mortalidad del pino ponderosa (Pinus ponderosa Engelm.) (34\% de árboles muertos) entre 2002 y 2016 en parcelas no quemadas, junto con similar mortalidad en parcelas con severidad moderada a alta, mostraron que aún las especies más tolerantes a la sequía en nuestro sitio de estudio fueron afectadas por excepcionales condiciones de calor y sequía. La regeneración inmediata post-fuego fue dominada por rebrotes de álamo temblón a través de todas las severidades de fuego. Para 2016, sin embargo, las densidades del álamo temblón fueron menores en las parcelas no quemadas, y en las quemadas a severidades moderadas a altas, que en las observadas previo al fuego, y también que las plántulas de coníferas se establecían primariamente en parcelas no quemadas. Las plántulas de pino ponderosa se establecieron entre 2011 y 2016 y fueron observadas solo en una parcela no quemada en 2016. La falta de regeneración de pino y el tamaño relativamente pequeño de los parches de alta severidad en el incendio de Leroux sugieren que otros factores aparte de la dispersión de semillas limitaron la regeneración del pino ponderosa.

Conclusiones: Una mortalidad substancial (68\% de pérdida de árboles) y reducción del 39\% del área basal en los 15 años de estudio, más una regeneración variable de álamo temblón y laxa de coníferas, llevaron a condiciones de no recuperación del dosel forestal y al establecimiento de rodales aislados de álamo temblón. Aunque pequeño en tamaño, el incendio de Leroux proveyó de un ejemplo de cambios continuos en la comunidad vegetal post fuego derivado del incremento de temperaturas y sequía. De esta manera, las interacciones entre el cambio climático y los incendios pueden acelerar los cambios en estructura y composición de los ecosistemas forestales del Sudoeste de EEUU.

\section{Background}

Wildfire and climate interact to play complex roles in determining tree mortality, species establishment, and forest composition. As climatic patterns trend towards warmer and drier conditions, and the occurrence and size of forest wildfires increase across the southwestern US (Westerling et al. 2006; Dennison et al. 2014; Hurteau et al. 2014), accelerated vegetation changes are predicted for many forested ecosystems (Allen et al. 2015). Under high $\mathrm{CO}_{2}$ emission scenarios, models suggest widespread tree mortality and forest loss in the Southwest (Diggins et al. 2010, Tarancón et al. 2014, Stoddard et al. 2015). Other models suggest the need for migration of tree species to track suitable climatic conditions (Laughlin et al. 2011). Increased temperature and drought stress in the early twenty-first century have shown to contribute to decreased conifer regeneration (Stevens-Rumann et al. 2018). Although climate change may be the primary factor driving ecological responses, disturbances such as wildfires are likely to interact with climate in complex ways, with uncertain effects on forest structure and composition (Donato et al. 2016). Shifts in forest composition and tree species distributions in response to wildfire and climate are likely to be most readily observed in transition zones, where species are near their environmental limits (Adams and Kolb 2004; Mast and Wolf 2004). Monitoring indicators of change, such as tree mortality and regeneration at these transition zones, can provide greater insights concerning processes that influence both shifts in composition as well as persistence of key species.

On topographically diverse landscapes in the southwestern US, aspect and steep vertical gradients delineate ecological zones, often over short horizontal distances (Merriam 1890; Whittaker and Niering 1975). In addition, composition and vegetation dynamics are determined through disturbance-microclimate interactions (Grissino-Mayer et al. 1995, Stephens 2001, Beaty and Taylor 2008, Iniguez et al. 2009, Rodman et al. 2016). 
For example, stand structure and composition of dry mixed-conifer forests were historically regulated by frequent, low-severity fire intermixed with high-severity patches (Swetnam and Baisan 1996; Fulé et al. 2003; Margolis and Balmat 2009; Huffman et al. 2015). Interruption of natural fire cycles through intensive land use since the late $1800 \mathrm{~s}$ is responsible for substantial alterations in structure and function of these ecosystems (Covington and Moore 1994; Allen et al. 2002; Seager et al. 2007). As a result of fire exclusion, dry mixed-conifer and ponderosa pine (Pinus ponderosa Engelm.) forests have become spatially homogenized with smaller, younger trees and have shifted in dominance towards more shade- and fire-intolerant species (Huffman et al. 2015; Strahan et al. 2016). Thus, prior to intensive anthropogenic changes, frequent surface fire acted to edit (i.e., filter) species assemblages, and supersede climatic influences.

Often, fire severity is used to predict successional trajectories and rates of ecosystem recovery (Lentile et al. 2007), though these processes are influenced by life history traits of species in the community (Turner et al. 1998; Westoby et al. 2002). For example, ponderosa pine, one of the most fire-resistant and drought-tolerant species in Western forests, has thick bark and protective buds that can often tolerate moderate fire intensity (Vines 1968; Reynolds et al. 2013). In mixed communities, ponderosa pine would be expected to better resist moderate-severity fire and fill space left by mortality of less tolerant species. In contrast, quaking aspen (Populus tremuloides Michx.) is susceptible to top-kill from low-intensity fires due to its thin bark, but this species often resprouts vigorously (Brown and DeByle 1987). After high-severity fire, aspen would be expected to rapidly recolonize a site through vegetative reproduction. Given warming climate and drier conditions, post-fire recovery trajectories, even for fire-resistant and resilient species, are subject to change. To better understand complex post-fire successional responses in mixed-species forests, long-term monitoring is necessary.

Cocke et al. (2005a) classified four fire severities (unburned, low, moderate, and high) using the differenced normalized burn ratio $(\triangle \mathrm{NBR})$ for pre- and post-fire remote imagery (Key and Benson 2006) one year following the Leroux wildfire that occurred in 2001 on the San Francisco Peaks in northern Arizona, USA. They also took advantage of pre-fire measurements and 1-year post-fire measurements on permanent plots to compare first order fire effects within severity types as classified by $\triangle N B R$. Cocke et al. (2005a) concluded that satellite-based severity classifications were strongly associated with ground-based fire severity assessments from permanent plots. In this study, we remeasured the plots described by Cocke et al. (2005a) to extend our understanding of responses to 15 years post fire. In addition, from 1996 to 2016, the Southwest region experienced a period of severe drought (Weiss et al. 2009; Garfin et al. 2013), and this provided a unique opportunity to analyze effects of drought on mutli-year responses to wildfire. We asked the following research questions: (i) What are the prolonged effects of a wildfire on overstory structure and tree mortality? (ii) Is long-term tree mortality related to initial fire severity? and (iii) What are the effects of fire severity on tree regeneration over time? The intent of this study was to quantify changes in forest structure through time within the extent of the Leroux Fire, and to compare tree mortality and regeneration within fire severity classes.

\section{Methods}

Study area

Our study area was the site of the Leroux Fire, located within the Kachina Peaks Wilderness Area, on the Coconino National Forest, north of Flagstaff, Arizona, USA $\left(35^{\circ} 18^{\prime} \mathrm{N}, 111^{\circ} 41^{\prime} \mathrm{W}\right)$. The Leroux Fire was a human-ignited wildfire that started on 11 June 2001 and burned $~ 500$ ha on the south-facing slope of Agassiz Peak, between 2490 and 3145 m (details described in Cocke et al. 2005b. The fire burned primarily in a ponderosa pine and mixed-conifer forest ecotone. Tree species included ponderosa pine, quaking aspen (hereafter "aspen"), Douglas-fir (Pseudotsuga menziesii [Mirb.] Franco), and limber pine (Pinus flexilis James). In order of tolerance to drought and fire, ponderosa pine $>$ Douglas-fir $>$ limber pine $>$ aspen (Reynolds et al. 2013; Rodman et al. 2016). Limber pine and Douglas-fir are considered intermediate with regards to shade tolerance, while ponderosa pine and aspen have a low shade tolerance. Ponderosa pine seedlings can take 4 to 19 years to grow to $40 \mathrm{~cm}$ (Puhlick et al. 2013), while Douglas-fir and limber pine grow slower, taking 14 to 25 years to grow to $40 \mathrm{~cm}$ (Heinlein et al. 2005). Aspen is the only root-sprouting species of the four tree species. Perennial native bunch grasses (Festuca arizonica Vasey, Muhlenbergia montana Nutt., Poa fendleriana Steud., and Elymus elymoides [Raf.] Swezey) were dominant in the pre-fire forest understory (Fisher and Fulé 2004).

\section{Data collection}

In 2002, Cocke et al. (2005a) remeasured 18 burned plots and 6 unburned plots that were established prior to the Leroux Fire. Plots were 0.1 ha $(20 \mathrm{~m} \times 50 \mathrm{~m})$ in size and spaced on a systematic rectangular grid $300 \mathrm{~m}$ north to south, and 300 to $600 \mathrm{~m}$ east to west. All trees were tagged and tree measurements included species, condition, diameter at breast height (dbh; $1.37 \mathrm{~m}$ above 
ground), total height, and crown base height. Trees $\geq 15 \mathrm{~cm}$ dbh were measured on the entire plots; trees between 2.5 and $15 \mathrm{~cm}$ dbh were measured on a 0.025 ha subplot. Seedlings and ramets $<2.5 \mathrm{~cm}$ dbh and $>15 \mathrm{~cm}$ tall were considered regeneration and tallied by species on a $50 \mathrm{~m}^{2}$ subplot (NPS 2003). Seedlings and ramets $<15 \mathrm{~cm}$ tall were consider germinates, not established regeneration, and excluded from analysis. Cocke et al. (2005a) created a burn severity map for the extent of the Leroux Fire from Landsat 7 imagery by calculating the change in the normalized burn ratio $(\triangle \mathrm{NBR})$ of bands 4 and 7 from pre-fire (2000) and post-fire (2002) imagery (Key and Benson 2006). These burn severity classifications were then verified with composite burn index (CBI) ground-truthing plots (Key and Benson 2006). The burn severity classifications indicated $12 \%$ of the total area within the fire perimeter was unburned, 52\% was low severity, $29 \%$ was moderate burn severity, and $7 \%$ was high burn severity (Fig. 1). The resulting severity map was then used to classify the 24 permanent plots by severity levels. Six plots were classified as low burn severity and six as unburned, eight classified as moderate urn severity and four as high burn severity. We remeasured the same 24 plots in 2011 and 2016.

\section{Analysis}

Means for tree density and basal area (BA) for describing conditions for the entire Leroux Fire (whole-fire level) were estimated using area-weighted means (ATW) by fire severity class proportions and relative sampling intensity. Weighting severity class means by their relative proportion of total fire area provides a more accurate estimate of whole-fire conditions compared to assuming that plots represent the variability in fire severity when randomly sampled. To test for differences in live overstory tree density and basal area (BA) between sample years, we used one-way analysis of variance (ANOVA). Tree density was transformed (square root) in order to meet normality and homoscedasticity assumptions of ANOVA. When significant main effects were found, Tukey's honestly significant difference (HSD) post hoc multiple comparisons test was used to

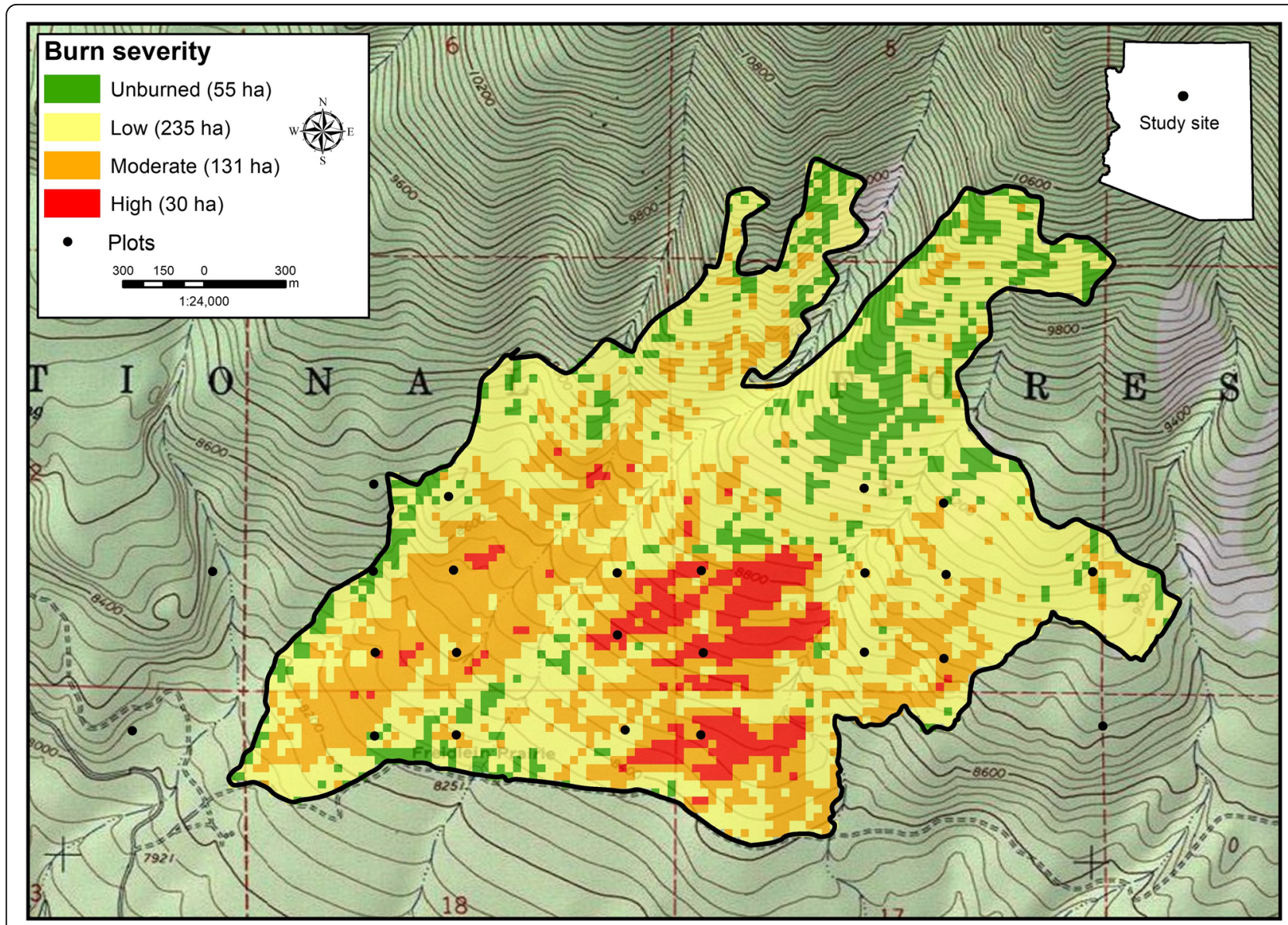

Fig. 1 Fire severities for the 2001 Leroux Fire on the San Francisco Peaks in northern Arizona, USA, and location of permanent remeasured plots. Cocke et al. (2005a) developed fire severity classes using the differenced normalized burn ratio ( $\Delta$ NBR) for pre- and post-fire Landsat 7 imagery and then verified with composite burn index (CBI) ground-truthing plots 
test for pairwise differences between sample years. Differences in overstory species composition between pre-fire and 2016 (post fire) were analyzed using permutational multivariate analysis (PERMANOVA) with Bray-Curtis dissimilarity distance measure (Anderson 2001; Faith et al. 1987). Differences in overstory composition were tested using plot level importance values calculated by summing relative tree density and relative basal area for each tree species. This index provides a measure of relative dominance of a given species in a community (Strahan et al. 2016). Because plots were not independent in treatment (Leroux Fire) and measurement year, inferences drawn from our analyses are limited to this individual fire event.

To test for differences in tree mortality (i.e., tree density loss) between severity classes and post-fire years, we used Chi-square tests $(2 \times 2$ contingency tables). We calculated average percent tree mortality by tree density (tree $\mathrm{ha}^{-1}$ ) for each species and for all species combined by fire severity classes and by post-fire year. We tested for differences in relative mortality among fire severities for each species and for all species combined within measurement years. We also compared initial mortality (2000 to 2002) to cumulative secondary mortality (2002 to 2016) within each severity class for each species and all species combined. For each pairwise comparison, we used a Bonferroni correction to account for multiple contrasts. For 2016 observations, percentage of plots with regeneration was calculated by fire severity class and compared using Chi-square tests $(2 \times 2$ contingency table). Total regeneration was compared between fire severity classes within each measurement year with a non-parametric Kruskal-Wallis test due to non-normal data distributions. All analyses were conducted using $\alpha=0.05$.

\section{Results}

Whole-fire overstory changes

Compared with pre-fire (2000) conditions, live overstory density and BA were significantly reduced by the Leroux Fire $(P<0.001$ for both tree density and BA measured in 2002) and continued to decline through year 2011 (Fig. 2). Before the fire, area-weighted mean (AWM) tree density was 686.2 trees $\mathrm{ha}^{-1}$ and area-weighted mean BA was $38.2 \mathrm{~m}^{2} \mathrm{ha}^{-1}$ (Fig. 2). Pre-fire tree diameter distribution followed a reverse-J distribution with relatively high numbers of small trees (Fig. 3). In 2002, AWM tree density was 344.2 trees $\mathrm{ha}^{-1}$, a decline of $50 \%$ from pre-fire tree densities. Average BA declined by $27 \%$ from pre-fire levels and AWM was $27.8 \mathrm{~m}^{2} \mathrm{ha}^{-1}$ in 2002. Initial post-fire mortality (2000 to 2002) occurred primarily (71\% of total mortality) in the smallest diameter class (Fig. 3). Initial tree loss for each species ranged between 40 and 64\% (Fig. 3). Live tree density and BA declined by $34 \%\left(118\right.$ trees ha $\left.{ }^{-1}\right)$ and $19 \%\left(5.4 \mathrm{~m}^{2} \mathrm{ha}^{-1}\right)$, respectively, from 2002 to 2011. Mortality from 2002 to 2011, subsequent to the initial post-fire response, ranged from 19 to $42 \%$ across all diameter classes (Fig. 3). Aspen tree mortality from 2002 to 2011 was disproportionate (52\%) compared to conifer species in the fire $(<39 \%)$. Average tree density continued to decrease such that, by 2016, density had decreased $68 \%$ to an average of 218.5 trees $\mathrm{ha}^{-1}$. Average BA slightly decreased (19\%) from 2002 to 2011. By 2016, BA averaged $23.2 \mathrm{~m}^{2} \mathrm{ha}^{-1}$, which was $39 \%$ below pre-fire BA. In 2016, diameter distributions were unimodal, with a slight peak in the $<20 \mathrm{~cm}$ diameter class.

Prior to the fire, ponderosa pine made up $60 \%$ of total tree density (excluding regeneration) and $62 \%$ of the BA, on average. Aspen made up 18\% and 14\%, limber pine made up $12 \%$ and $10 \%$, and Douglas-fir was $10 \%$ and $5 \%$, respectively, of pre-fire tree density and BA.
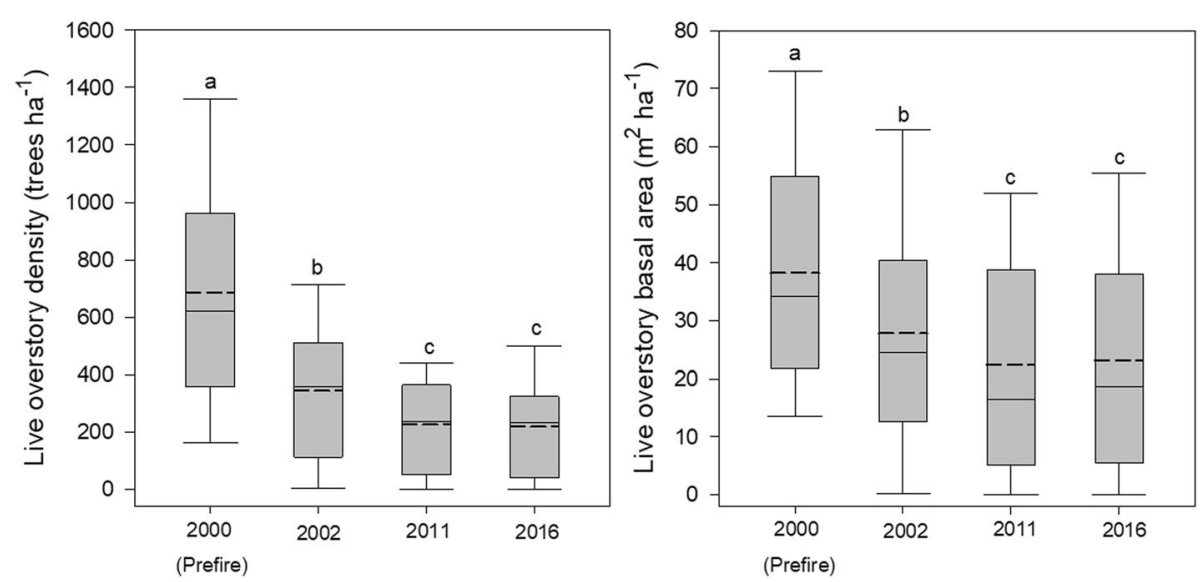

Fig. 2 Area-weighted means and standard deviations for live tree density and basal area by measurement year within the Leroux Fire in northern Arizona, USA. Different lowercase letters denote statistical significance $(P<0.05)$ between measurement-year means 

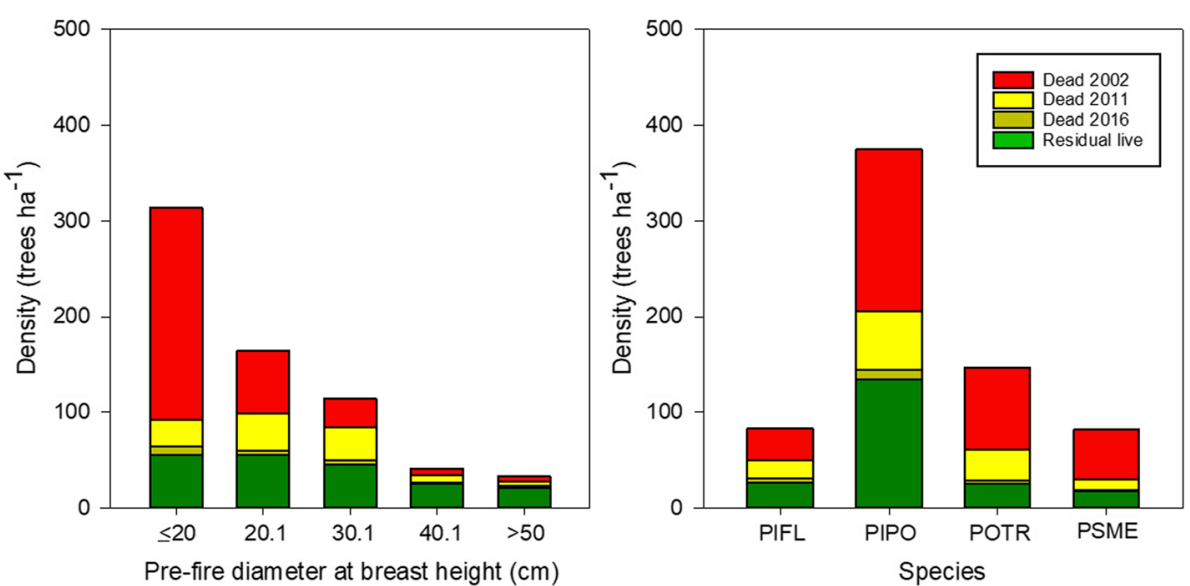

Fig. 3 Area-weighted mean for dead trees and living trees of pre-fire live ovestory (tree $=d b h \geq 2.5 \mathrm{~cm}$ and height $>1.4 \mathrm{~m}$ ) by pre-fire diameters and by species within the Leroux Fire perimeter. PIPO = Pinus ponderosa, POTR = Populus tremuloides, PIFL = Pinus flexilis, and PSME = Pseudotsuga menziesii

Overstory species composition (based on species importance values) in 2016 was similar (PERMANOVA $P=0$. 20) to pre-fire composition. In 2016, ponderosa pine composed $66 \%$ of live post-fire trees and $67 \%$ of BA. Aspen made up $15 \%$ of tree density and $19 \%$ of BA; limber pine accounted for $12 \%$ and $11 \%$ of tree density and $\mathrm{BA}$, respectively; and Douglas-fir made up $7 \%$ of tree density and $7 \%$ of BA.

\section{Fire severity effects on overstory}

Compared with pre-fire (2000) conditions, live tree densities were significantly $(P<0.05)$ lower in all burn severity classes in 2016 (Fig. 4). Initial tree mortality (i.e., tree density decreases) from 2000 to 2002 was significantly higher in moderate-severity plots compared to unburned, low-, and high-severity plots $\left(X^{2}=120\right.$ to $424, P<0.0125$;
Table 1). On average, tree densities declined 12\% (79 trees ha $\left.{ }^{-1}\right), 39 \%\left(216\right.$ trees ha $\left.{ }^{-1}\right), 69 \%\left(572\right.$ trees ha $\left.{ }^{-1}\right)$, and 44\% (612 trees $\left.\mathrm{ha}^{-1}\right)$ in unburned, low-, moderate-, and high-severity plots, respectively. Tree mortality (2000 to 2002) of all species generally was greater in moderate- and high-severity plots compared to unburned and low-severity plots (Table 1). Secondary tree mortality (both 2002 to 2011 and 2002 to 2016) was not statistically different among low-, moderate- and high-severity plots (Table 1), but mortality in all three burned classes was significantly higher than that of unburned plots $\left(X^{2}=12\right.$ to $19, P<0.0125)$. Tree mortality from 2002 to 2016 was most pronounced on high- (40\% or 319 trees ha $\left.{ }^{-1}\right)$ and low-severity $\left(40 \%\right.$ or 134 trees $\mathrm{ha}^{-1}$ ) plots, followed by those classified as moderate-sevrity ( $30 \%$ or 78 trees ha ${ }^{-1}$ ) and unburned plots $\left(18 \%\right.$ or 107 trees $\left.\mathrm{ha}^{-1}\right)$. One
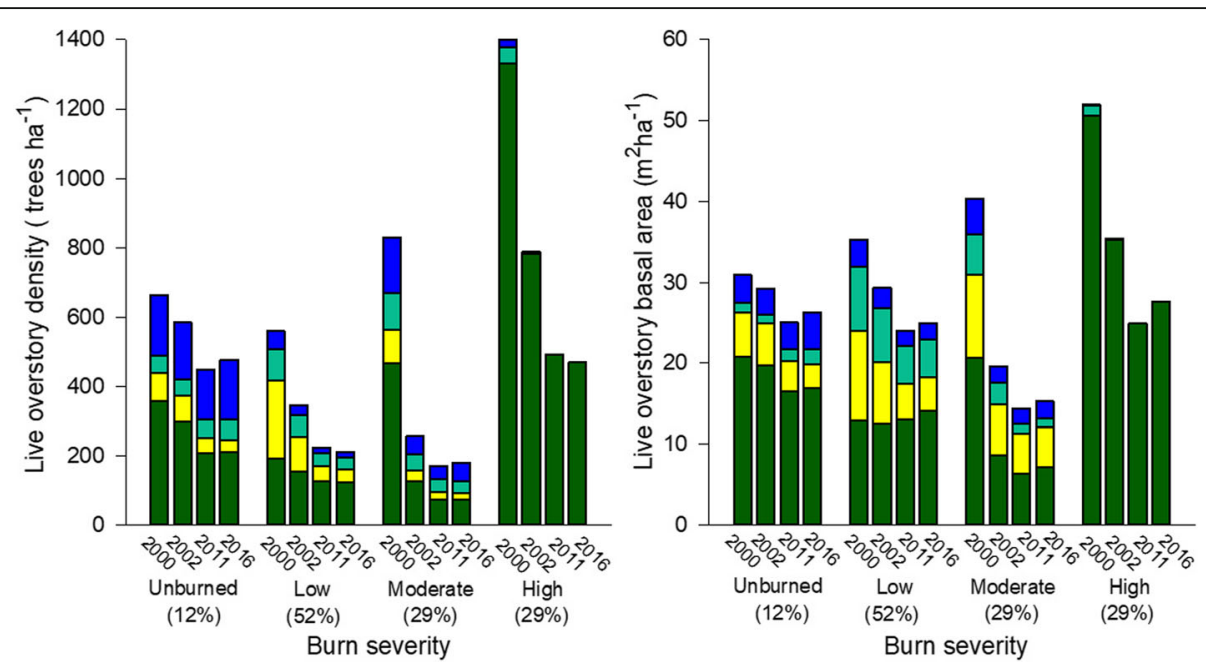

Fig. 4 Forest characteristics (tree density, basal area) by species, burn severity, and by time (pre-fire (2000) and post-fire (2002, 2011, and 2016)). Also shown are percentages of each burn severity within Leroux Fire. PIPO $=$ Pinus ponderosa, POTR $=$ Populus tremuloides, PIFL $=$ Pinus flexilis, and PSME = Pseudotsuga menziesii 
Table 1 Initial tree mortality (2000 to 2002) and secondary mortality (2002 to 2011 and 2002 to 2016) by fire severities and species following the 2001 Leroux Fire, Arizona, USA. Tree mortality (\% tree density) is the relative difference in tree density. Fire severity differences (within year) by total and species are indicated by superscripted letters. Initial and delayed mortality differences by total and species are indicated by bolded text. All alpha levels were adjusted using a Bonferonni correction (either $P \leq 0.0125$ or $P \leq 0.025)$. ${ }^{~} \mathrm{PIFL}=$ Pinus flexilis, $\mathrm{PIPO}=$ Pinus ponderosa, $\mathrm{POTR}=$ Populus tremuloides, and PSME $=$ Pseudotsuga menziesii

\begin{tabular}{|c|c|c|c|c|c|}
\hline \multirow[b]{2}{*}{ Years } & \multirow[b]{2}{*}{ Species $^{1}$} & \multicolumn{4}{|c|}{ Tree mortality (\% tree density) by fire severity class } \\
\hline & & Unburned & Low & Moderate & High \\
\hline \multirow[t]{5}{*}{2000 to 2002} & Total & $13.1^{\mathrm{a}}$ & $38.7^{b}$ & $68.8^{\complement}$ & $41.1^{b}$ \\
\hline & PIFL & $13.1^{\mathrm{a}}$ & $22.8^{\mathrm{a}}$ & $53.5^{\mathrm{b}}$ & $83.3^{c}$ \\
\hline & PIPO & $16.2^{\mathrm{a}}$ & $20.2^{\mathrm{a}}$ & $73.1^{\mathrm{b}}$ & $38.9^{\circ}$ \\
\hline & POTR & $4.3^{\mathrm{a}}$ & $56.3^{b}$ & $68.7^{\mathrm{b}}$ & \\
\hline & PSME & $10.8^{\mathrm{a}}$ & $50.0^{\mathrm{b}}$ & $66.6^{\mathrm{bc}}$ & $100.0^{\circ}$ \\
\hline \multirow[t]{5}{*}{2002 to 2011} & Total & $23.2^{\mathrm{a}}$ & $34.9^{\mathrm{b}}$ & $35.2^{\mathrm{b}}$ & $34.7^{\mathrm{b}}$ \\
\hline & PIFL & $0.0^{\mathrm{a}}$ & $38.2^{b}$ & $23.5^{\mathrm{b}}$ & $100.0^{\circ}$ \\
\hline & PIPO & $31.6^{\mathrm{a}}$ & $17.2^{b}$ & $42.5^{\mathrm{a}}$ & $34.0^{\circ}$ \\
\hline & POTR & 42.2 & 55.2 & 41.7 & \\
\hline & PSME & $0.0^{\mathrm{a}}$ & $50.0^{\mathrm{b}}$ & $25.0^{\mathrm{b}}$ & \\
\hline \multirow[t]{5}{*}{2002 to 2016} & Total & $26.6^{a}$ & $41.1^{b}$ & $41.7^{b}$ & $38.6^{b}$ \\
\hline & PIFL & $0.0^{\mathrm{a}}$ & $44.2^{b}$ & $39.3^{b}$ & $100.0^{\circ}$ \\
\hline & PIPO & $34.2^{\mathrm{ab}}$ & $22.9^{\mathrm{a}}$ & $46.5^{\mathrm{b}}$ & $38.0^{b}$ \\
\hline & POTR & 55.5 & 62.1 & 50.1 & \\
\hline & PSME & $0.0^{\mathrm{a}}$ & $56.2^{b}$ & $27.5^{\mathrm{b}}$ & \\
\hline
\end{tabular}

high-severity plot and three moderate-severity plots had no live overstory trees remaining in 2016. Tree mortality from 2002 to 2016 varied by species, with aspens experiencing disproportionately high mortality ( 46 to $62 \%$ tree loss) across all fire severities. Mortality from 2002 to 2016 for all species except aspen generally followed the same patterns as all species combined, with no differences among the different burned severity classes but significantly greater than unburned plots (Table 1). By 2016, tree densities averaged 477.1 trees $\mathrm{ha}^{-1}, 210.4$ trees $\mathrm{ha}^{-1}$, 179.2 trees ha ${ }^{-1}$, and 469.8 trees ha ${ }^{-1}$, in unburned, low-, moderate- and high-severity plots, respectively. Changes in BA followed the same pattern as tree densities. However, BA in 2016 was significantly $(P<0.05)$ less than pre-fire conditions only on moderate- and high-severity plots (Fig. 4). On average, BA declined 15\%, 29\%, 62\%, and $47 \%$ on plots classified as unburned, low, moderate and high severity, respectively. By 2016, BA averaged $26.3 \mathrm{~m}^{2} \mathrm{ha}^{-1}, \quad 24.9 \mathrm{~m}^{2} \mathrm{ha}^{-1}, 15.3 \mathrm{~m}^{2} \mathrm{ha}^{-1}$, and $27.6 \mathrm{~m}^{2} \mathrm{ha}^{-1}$, in unburned, low-, moderate-, and high-severity plots, respectively.

Significantly more tree mortality (i.e., tree density decreases) occurred initially (2000 to 2002) following the Leroux Fire in moderate-severity plots than from 2002 to $2016\left(x^{2}=61.3, P<0.025\right)$, whereas mortality from 2002 to 2016 in unburned plots was significantly higher than initial (2000 to 2002) fire mortality $\left(x^{2}=31.3, P<0.025\right)$. Initial fire mortality and mortality from 2002 to 2016 was not significantly different within low- and high-severity plots. Differences between initial and subsequent secondary mortality by individual species were variable within each burn severity (Table 1).

\section{Fire severity effects on tree regeneration}

Total regeneration did not differ significantly within sampling years among fire severity classes in the Leroux Fire (Fig. 5). Pre-fire (2000) regeneration species composition within the entire fire was $47 \%$ aspen, $29 \%$ ponderosa pine, $12 \%$ limber pine, and 12\% Douglas-fir. At this time, tree regeneration was observed on $50 \%$ of the plots. One year after the fire (2002), aspen densities increased $335 \% \quad\left(+688\right.$ stems $\left.\mathrm{ha}^{-1}\right), \quad 280 \%$ $\left(+1053\right.$ stems ha $\left.{ }^{-1}\right), 1781 \%\left(+3206\right.$ stems $\left.\mathrm{ha}^{-1}\right)$, and $600 \%\left(+303\right.$ stems $\left.\mathrm{ha}^{-1}\right)$ in unburned, low-, moderate-, and high-severity plots, respectively. Between 2002 and 2011, aspen densities within all severity classes declined 36 to 204 stems ha $^{-1}$ below pre-fire densities (Fig. 5). No aspen regeneration was found in high-severity plots in 2011 or 2016. In 2016, aspen densities were $50 \%$ and $14 \%$ less than pre-fire values, in unburned and moderate severity plots, respectively, but increased $475 \%$ $\left(+1782\right.$ stems $\left.\mathrm{ha}^{-1}\right)$ in low-severity plots and exceeded initial post-fire numbers by $51 \%$. Prior to the fire, ponderosa pine densities averaged 0 seedlings $\mathrm{ha}^{-1}, 0$ seedlings ha ${ }^{-1}, 129$ seedlings ha ${ }^{-1}$, and 354 seedlings ha ${ }^{-1}$ in unburned, low-, moderate-, and high-severity plots, 


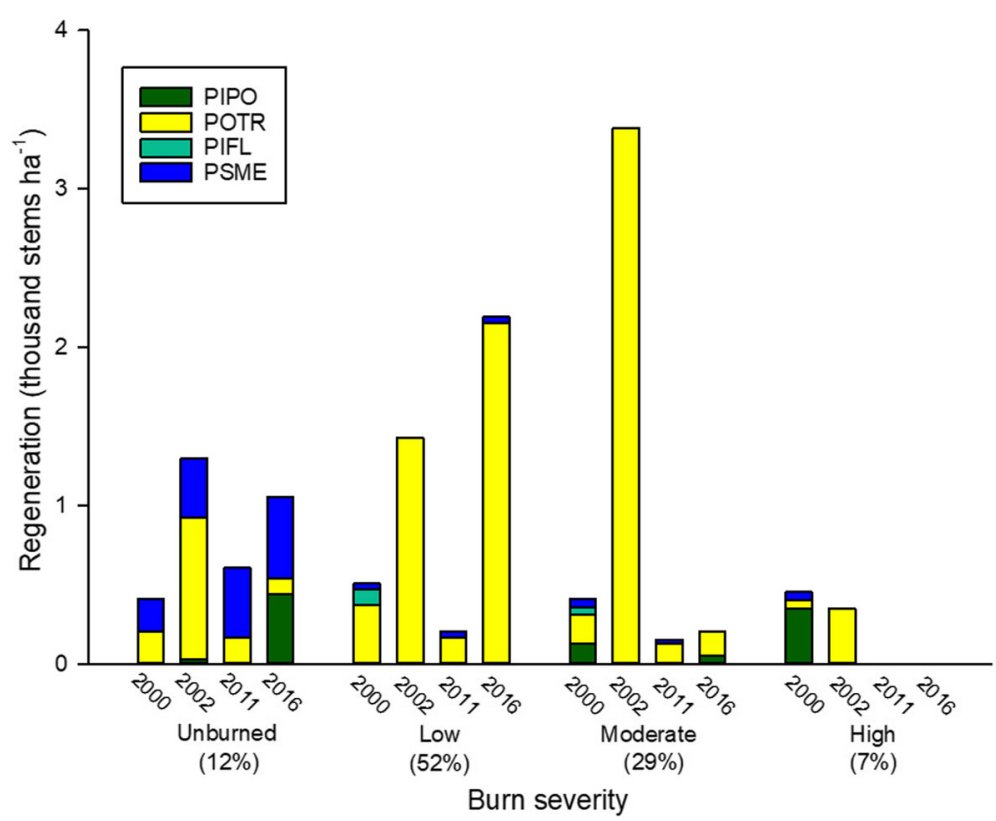

Fig. 5 Mean regeneration ( $<2.5 \mathrm{~cm}$ dbh and $>15 \mathrm{~cm}$ height) by species, burn severity, and by time (pre-fire 2000; post-fire 2002, 2011, and 2016). Also shown are percentages of each burn severity within Leroux Fire. PIPO = Pinus ponderosa, POTR $=$ Populus tremuloides, PIFL $=$ Pinus flexilis, and PSME = Pseudotsuga menziesii

respectively. One year after the fire, no ponderosa pine seedlings were found within low-, moderate-, or high-severity plots and remained absent 15 years after the fire in both low- and high-severity plots (Fig. 5). In 2016, ponderosa pine seedlings were found on one (13\%) moderate-severity plot with a density of 406 seedlings ha ${ }^{-1}$ and three unburned plots $(50 \%)$ with densities ranging from 204 to 1851 seedlings $\mathrm{ha}^{-1}$. One year after the fire, Douglas-fir seedlings were not found on burned plots, and remained absent in moderate- and high-severity plots in 2016. In 2016, Douglas-fir seedlings equaled densities ( 34 seedlings $\mathrm{ha}^{-1}$ ) found pre fire in low-severity plots and increased $150 \%$ in unburned plots compared to pre-fire densities (203 seedling ha ${ }^{-1}$ ). Prior to the Leroux Fire, limber pine was found on low-severity (averaged 101 seedlings $\mathrm{ha}^{-1}$ ) and moderate-severity (averaged 51 seedlings $\mathrm{ha}^{-1}$ ) plots. No limber pine seedlings were observed on any post-fire plots, including unburned plots.

By 2016, regeneration species composition within the Leroux Fire was $85 \%$ aspen, $14 \%$ ponderosa pine, and $1 \%$ Douglas-fir. In 2016, the percentage of plots occupied by regeneration was not significantly different among fire severity classes. Regeneration was observed on $37.5 \%$ of the plots and tended to occur more commonly on unburned plots.

\section{Discussion}

The 2001 Leroux Fire burned mainly as low (52\%) to moderate severity $(29 \%)$. This resulted in substantial differences in post-fire tree density and basal area, but did not significantly affect overstory species composition within this ponderosa pine and mixed-conifer ecotone. Tree density and BA continued to decrease over time and mortality remained nearly constant over 15 years within low-, moderate-, and high-severity classes. Thus, initial fire severity was not strongly related to longer-term patterns of mortality. Although regeneration was highly variable across fire severity classes and through time, quaking aspen sprouts accounted for $85 \%$ of the tree seedlings and ramets observed. Overstory changes were concentrated in smaller tree size classes $(\leq 20 \mathrm{~cm} \mathrm{dbh})$ and, compared with pre-fire, resulting structure in lowand moderate-severity areas more closely resembled historical (i.e., pre 1900) conditions (Cocke et al. 2005b). Taken together, these results suggest that fire, subsequent climatic conditions, and likely other secondary factors interacted to reduce tree density and limit establishment of conifers. The successional trajectory of the Leroux Fire is unclear, particularly as climate warms and drought periods become more severe or common (Laughlin et al. 2011). It is likely that ponderosa pine will persist in the overstory over the next few decades, and large, seed-bearing trees may provide a seed source for regeneration under favorable environmental conditions in the future. However, continued lack of conifer regeneration, such as we observed in this 15 -year study, may, with time, lead to novel ecological conditions. 


\section{Severity patterns}

Although fire severity classification reportedly described the variability in first-order fire effects at this site (see Cocke et al. 2005a), secondary tree mortality was indistinguishable among the burned (low, moderate, high) severity classes from 2002 to 2016, and ranged from 38 to $42 \%$ for all species combined. In low-severity plots, secondary tree mortality ranged from 26 to $62 \%$, which may be high compared with patterns of secondary mortality reported for low-severity wildfire areas in western US dry forests elsewhere (Keyser et al. 2008; Fornwalt et al. 2018). In addition, tree mortality on unburned plots from 2002 to 2016 was $26 \%$, double the initial mortality (2000 to 2002) one year following the Leroux Fire (Fig. 4). These results point to climate-related factors leading to considerable tree mortality and limited conifer regeneration over the study period. Secondary mortality within the Leroux Fire was likely driven, at least in part, by drought conditions. Climate summaries indicate that drought conditions and higher than average temperatures occurred over the study period (Fig. 6). In fact, from 1996 to 2007, northern Arizona experienced one of the most extensive and severe droughts recorded since the 1950s (Weiss et al. 2009). Climate reconstructions from tree-ring data indicate that 2002 was the third driest year in the last 1400 years (Salzer and Kipfmueller 2005). In addition, average daily temperatures for the 2001 to 2010 decade were the highest on record since 1900 , and this decade was also one of the warmest periods of comparable length in at least 600 years (Garfin et al. 2013).

Numerous studies have documented widespread tree mortality during the latter twentieth and early twenty-first centuries, driven primarily by regional warming trends and drought (Van Mantgem et al. 2009;
Allen et al. 2010; Williams et al. 2013; Clark et al. 2016). Drought and high temperature in combination is known to increase rate of carbon starvation in Southwestern conifers and exacerbate tree mortality (Adams et al. 2009). Several studies have documented punctuated aspen mortality coinciding with the severe drought of 2002, along with subsequent mortality due to insects and disease (Fairweather et al. 2008; Ganey and Vojta 2011; Kane and Kolb 2014). Similar aspen mortality over the last two decades has been documented and linked to drought and higher temperatures as well as to insect-caused defoliation, herbivory, and pathogens, particularly on marginal sites (Rehfeldt et al. 2009; Zegler et al. 2012; Worrall et al. 2013). Our observations of high aspen mortality from 2011 to 2016 add to concerns for this species in a warming climate. Further, ponderosa pine mortality (34\%) between 2002 and 2016 on unburned plots, along with similar mortality on moderateand high-severity plots, show that even the most drought-tolerant species on our site was apparently affected by adverse climatic conditions.

\section{Current conditions}

Forest structural changes resulting from fire and secondary mortality, particularly reduction in small-diameter trees in areas of high pre-fire cover, appeared to move tree density and basal area closer to historical conditions (i.e., pre-fire-exclusion) at the site (Cocke et al. 2005b). For example, Cocke et al. (2005b) estimated historical tree densities and basal area to be 61.4 trees ha ${ }^{-} 1$ and $7.6 \mathrm{~m}^{2} \mathrm{ha}^{-1}$, respectively, for ponderosa pine, and 160.9 trees $\mathrm{ha}^{-1}$ and $17.9 \mathrm{~m}^{2} \mathrm{ha}^{-1}$, respectively, for mixed-conifer forests at the study site. Structural patterns similar to those occurring prior to intensive land uses and exclusion of natural surface fire are thought to
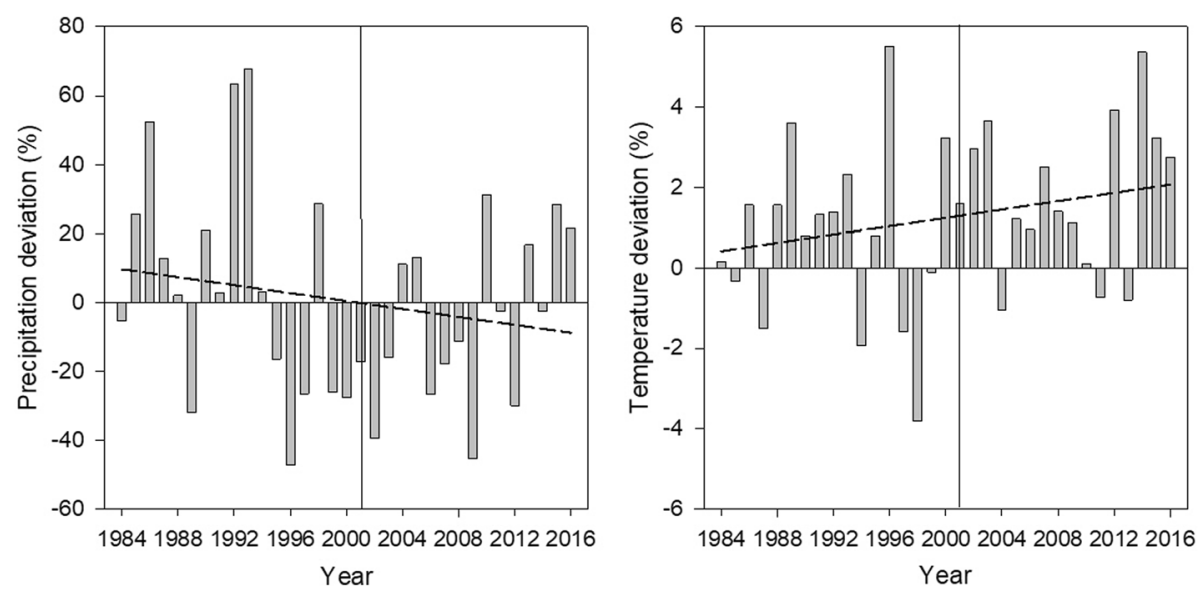

Fig. 6 Precipitation and temperature percent deviation (deviation from the long-term mean 1950 to 2016) spanning both 16 years prior to and after initial sampling from Pulliam Airport weather station (https://wrcc.dri.edu/cgi-bin/cliMAIN.pl?az3010) in Flagstaff, Arizona, USA. The vertical lines represent the year of the Leroux Fire and the dashed lines represents a linear fit for deviation as a function of year 
increase forest resiliency to subsequent disturbance and environmental stressors compared with dense stand conditions widely reported where frequent-fire regimes have been disrupted (Agee and Skinner 2005, Waltz et al. 2014, Stephens et al. 2016). Indeed, there is increasing interest in managing lightning ignitions to achieve ecological restoration objectives (Huffman et al. 2017). It is unclear whether several other aspects of structure and process at the site now more closely resemble historical ranges of variability. For example, tree species composition remained dominated by ponderosa pine 15 years after the Leroux Fire, whereas reconstructions of mixedconifer forests reported by Cocke et al. (2005b) show greater historical abundance of limber pine, aspen, and Douglas-fir. Loss of $52 \%$ and $57 \%$ of the large limber pine and Douglas-fir trees ( $>40 \mathrm{~cm}$ diameter), respectively, over the duration of the study (2000 to 2016) is also concerning but difficult to evaluate from a historical stand-structure aspect. Nevertheless, retaining large trees following fires is a conservational priority because they contribute to the overall ability of the stand to regenerate, and they represent a rare structural legacy that provides numerous ecosystem services. The loss of over half of both limber pine and Douglas-fir and the lack of regeneration of these species indicates either substantially longer periods of recovery toward a mixed-conifer forest, or a divergence from a historically mixed-conifer forest. Our data does not allow precise analysis of spatial patterns of trees, tree patches, or opening sizes, which are important attributes influencing ecological function in ponderosa pine and mixed-conifer forests (Rodman et al. 2016). Lastly, it is important to note that the Leroux Fire was human-caused, and management actions were organized around fire suppression, rather than intentionally allowing the fire to burn to provide explicit resource benefits.

\section{Future trajectory}

Increases in regeneration densities on our plots were driven by aspen, especially in low- and moderate-fire severity plots. Prolific aspen resprouting after fire is well documented (Bailey and Whitham 2002; Stoddard et al. 2015; Yocom-Kent et al. 2015). However, aspen sprouts in Southwestern forests commonly fail to reach tree stature if exposed to intensive herbivory, pathogens, or reburning (Fairweather et al. 2008; Zegler et al. 2012). In addition, aspen may reestablish on sites through top-kill and release of suppressed meristems, but changing climatic conditions and environmental stressors may reduce the range of persistence. In our study, aspen regeneration increased over $800 \%$ in 2002, then fell below pre-fire densities in 2011. Fairweather et al. (2008) found a similar trend on the San Francisco Peaks, vis-à- vis an increase of aspen sprouts following the death of mature trees in 2002, and then nearly all aspen sprouts died by 2007. Our regeneration data suggest that areas that initially burned with low severity are more likely to develop aspen stands and possibly mixed-conifer forest characteristics than those that burn under moderate or high severity.

In 2016, ponderosa pine seedlings were absent from all but one burned plot in the Leroux Fire site. The seedlings present apparently established between 2012 and 2016, as we found no ponderosa pine regeneration on any sample plots in 2011. The lack of pine regeneration and the relatively small size of high-severity patches in the Leroux Fire (Fig. 1) suggest factors other than seed dispersal limited ponderosa pine regeneration. Ponderosa pine establishment of 3.6 to 17 trees ha $^{-1}$ decade $^{-1}$ has been suggested as a minimum required to maintain open structural conditions similar to those prevailing prior to fire regime disruption (Bailey and Covington 2002). Densities observed in our study were below this range. Ouzts et al. (2015) found that recent wildfires (2000 to 2005) in Arizona and New Mexico, USA, tended to show low numbers of natural ponderosa pine regeneration, below densities desirable according to ecological restoration principles and estimated long-term survival. Similarly, Stevens-Rumann et al. (2018), in a multi-regional study of Western forests, found significant decreases in post-fire regeneration in the early twenty-first century compared with the end of the twentieth century, and regeneration failure was related to high moisture deficits during the period 2000 to 2015 . More monitoring is needed to determine successional trajectories at our site; however, our observations suggest that continued tree mortality and sparse conifer regeneration will lead to increases in non-forested conditions, or isolated aspen stands, within the Leroux Fire site.

\section{Conclusions}

The 2001 Leroux Fire burned across a ponderosa pine and mixed-conifer ecotone with mixed severity, with the majority (52\%) burning as low severity and likely reduced fuels to conditions that may reduce severity of future fire effects. Over 15 years of observation, this site experienced substantial secondary tree mortality, which was likely driven by drought and high temperatures. As climate models predict a warmer and drier climate throughout the southwestern US (Seager et al. 2007; Hurteau et al. 2014), geographic shifts and reductions in distribution of dominant tree species are likely for much of the region. Warmer temperatures and increasing frequency of droughts, along with disturbances such as wildfire, may push species past survival thresholds and 
preclude regeneration (Rehfeldt et al. 2006, 2009). Results from our study demonstrate potential for forest community changes following wildfire in a montane forest ecotone. Additional monitoring of this and other fire sites is essential for informing ecosystem management in the coming decades of changing climate.

\section{Acknowledgements}

We thank the staff and students of the Ecological Restoration Institute at Northern Arizona University for field and logistical support. The manuscript was improved tremendously by the comments of the associate editor and two anonymous reviewers. This work was supported by a grant provided by the US Department of Agriculture Forest Service. Northern Arizona University is an equal opportunity provider.

\section{Funding}

All funding provide by US Department of Agriculture Forest Service.

\section{Availability of data and materials}

Please contact author for data request.

\section{Authors' contributions}

MTS collected and compiled field data, conducted analyses, and wrote the manuscript. DWH was the Principal Investigator (PI), contributed to organization and conceptual ideas, editing, and writing the manuscript. PZF was the original PI, implemented experimental design, collected initial field data, and contributed to manuscript editing and manuscript preparation. JEC collected field data and contributed to manuscript preparation and editing. AJSM contributed to background analyses and manuscript editing. All authors read and approved the final manuscript.

\section{Ethics approval and consent to participate}

Not applicable.

\section{Consent for publication}

Not applicable.

\section{Competing interests}

The authors declare that they have no competing interests.

\section{Publisher's Note}

Springer Nature remains neutral with regard to jurisdictional claims in published maps and institutional affiliations.

\section{Author details}

'Northern Arizona University, Ecological Restoration Institute, P.O. Box 15017, Flagstaff, Arizona 86011, USA. ${ }^{2}$ Northern Arizona University, School of Forestry, Box 15018, Flagstaff, Arizona 86011, USA.

Received: 6 September 2018 Accepted: 19 September 2018 Published online: 27 December 2018

\section{References}

Adams, H.D., M. Guardiola-Claramonte, G.A. Barron-Gafford, J.C. Villegas, D.D. Breshears, C.B. Zou, P.A. Troch, and T.E. Huxman. 2009. Temperature sensitivity of drought-induced tree mortality portends increased regional dieoff under global-change-type drought. Proceedings of the National Academy of Sciences of the United States of America 106: 7063-7066 https://doi.org/10. 1073/pnas.0901438106

Adams, H.D., and T.E. Kolb. 2004. Drought responses of conifers in ecotone forests of northern Arizona: tree ring growth and leaf $\delta^{13} \mathrm{C}$. Oecologia 140 (2): 217-225 https://doi.org/10.1007/s00442-004-1585-4.

Agee, J.K., and C.N. Skinner. 2005. Basic principles of forest fuel reduction treatments. Forest Ecology and Management 211: 83-96.

Allen, C.D., D.D. Breshears, and N.G. McDowell. 2015. On underestimation of global vulnerability to tree mortality and forest die-off from hotter drought in the Anthropocene. Ecosphere 6 (129): 1-55 https://doi.org/10.1890/ES1500203.1.
Allen, C.D., A.K. Macalady, H. Chenchouni, D. Bachelet, N. McDowell, M. Vennetier, T. Kitzberger, A. Rigling, D.D. Breshears, E.T. Hogg, P. Gonzalez, R. Fensham, Z. Zhang, J. Castro, N. Demidova, J.H. Lim, G. Allard, S.W. Running, A. Semerci, and N. Cobb. 2010. A global overview of drought and heat-induced tree mortality reveals emerging climate change risk for foresters. Forest Ecology and Management 259: 660-684 https://doi.org/10.1016/j.foreco.2009.09.001.

Allen, C.D., M. Savage, D.A. Faulk, K.F. Suckling, T.W. Swetnam, T. Schulke, P.B. Stacey, P. Morgan, M. Hoffman, and J.T. Klingel. 2002. Ecological restoration of Southwestern ponderosa pine ecosystems: a broad perspective. Ecological Applications 12: 1418-1433.

Anderson, M.J. 2001. A new method for non-parametric multivariate analysis of variance. Australia Ecology 26: 32-46 https://doi.org/10.1046/j.1442-9993.2001. 01070.x

Bailey, J.D., and W.W. Covington. 2002. Evaluating ponderosa pine regeneration rates following ecological restoration treatments in northern Arizona, USA. Forest Ecology and Management 155: 271-278.

Bailey, J.K., and T.G. Whitham. 2002. Interactions among fire, aspen, and elk affect insect diversity: reversal of a community response. Ecology 83: 1701-1712.

Beaty, R.M., and A.H. Taylor. 2008. Fire history and the structure and dynamics of a mixed conifer forest landscape in the northern Sierra Nevada, Lake Tahoe Basin, California, USA. Forest Ecology and Management 255: 707-719.

Brown, J.K., and N.V. DeByle. 1987. Fire damage, mortality, and suckering in aspen. Canadian Journal of Forest Research 17: 1100-1109 https:/doi.org/10.1139/×87-168.

Clark, J.S., L. Iverson, C.W. Woodall, C.D. Allen, D.M. Bell, D.C. Bragg, A.W. D'Amato, F. W. Davis, M.H. Hersh, I. Ibanez, S.T. Jackson, S. Matthews, N. Pederson, M. Peters, M.W. Schwartz, K.M. Waring, and N.E. Zimmermann. 2016. The impacts of increasing drought on forest dynamics, structure, and biodiversity in the United States. Global Change Biology 22: 2329-2352 https://doi.org/10.1111/gcb.13160.

Cocke, A.E., P.Z. Fulé, and J.E. Crouse. 2005a. Comparison of burn severity assessments using differenced normalized burn ratio $(\triangle N B R)$ and ground data. International Journal Wildland Fire 14: 189-198 https://doi.org/10.1071/WF04010.

Cocke, A.E., P.Z. Fulé, and J.E. Crouse. 2005b. Forest change on a steep mountain gradient after extended fire exclusion: San Francisco Peaks, Arizona, USA. Journal of Applied Ecology 42: 814-823 https://doi.org/10.1111/j.1365-2664. 2005.01077.x

Covington, W.W. and M.M. Moore. 1994. Southwestern ponderosa forest structure: changes since Euro-American settlement. Journal of Forestry 92 (1): 39-47.

Dennison, P., S.C. Brewer, J.D. Arnold, and M.A. Moritz. 2014. Large wildfire trends in western United States, 1984-2011. Geophysical Prospecting 8: 2928-2933.

Diggins, C., P.Z. Fulé, J.P. Kaye, and W.W. Covington. 2010. Future climate affects management strategies for maintaining forest restoration treatments. International Journal Wildland Fire 19: 903-913 https://doi.org/10.1071/WF09109.

Donato, D.C., B.J. Harvey, and M.G. Turner. 2016. Regeneration of montane forests 24 years after the 1988 Yellowstone fires: a fire catalyzed shift in lower treelines? Ecosphere 7 (8): 1-16 https://doi.org/10.1002/ecs2.1410.

Fairweather, M., B. Geils, and M. Manthei. 2008. Aspen decline on the Coconino National Forest. In Proceedings of the 55th Western international forest disease work conference, 15-19 October 2007, ed. M.G. McWilliams, 53-62. Sedona: Oregon Department of Forestry, Salem.

Faith, D.P., P.R. Minchin, and L. Belbin. 1987. Compositional dissimilarity as a robust measure of ecological distance. Vegetatio 69: 57-68 https://doi.org/10. 1007/BF00038687.

Fornwalt, P.F, C.S. Stevens-Rumann, and B.J. Collins. 2018. Overstory structure and surface cover dynamics in the decade following the Hyaman Fire, Colorado. Forests 9: 152 https://doi.org/10.3390/f9030152

Fulé, P.Z., J.C. Crouse, T.A. Heinlein, M.M. Moore, W.W. Covington, and G. Verkamp. 2003. Mixed severity fire regime in a high-elevation forest of Grand Canyon, Arizona, USA. Landscape Ecology 18: 465-486 https:/doi.org/10.1023/A:1026012118011.

Ganey, J., and S. Vojta. 2011. Tree mortality in drought-stressed mixed-conifer and ponderosa pine forests, Arizona, USA. Forest Ecology and Management 261: 162-168.

Garfin, G., A. Jardine, R. Merideth, M. Black, and S. LeRoy, eds. 2013. Assessment of climate change in the Southwest United States: a report prepared for the National Climate Assessment. Washington, D.C.: Island Press https://doi.org/10. 5822/978-1-61091-484-0.

Grissino-Mayer, H.D., C.H. Baisan, and T.W. Swetnam. 1995. Fire history in the Pinaleño Mountains of southeastern Arizona: effects of human related disturbances. In Biodiversity and management of the Madrean Archipelago: the Sky Islands of southwestern United States and northwestern Mexico, ed. L.F. Debano, G.J. Gottfried, RH. Hamre, CB. Edminster, PF. Ffolliott, and A. Ortega-Rubio, 399-407. Fort Collins: USDA Forest Service General Technical Report RM-GTR-264. 
Heinlein, T.A., M.M. Moore, P.Z. Fulé, and W.W. Covington. 2005. Fire history and stand structure of two ponderosa pine-mixed-conifer sites: San Francisco Peaks, Arizona, USA. International Journal Wildland Fire 14: 307-320 https:// doi.org/10.1071/WF04060.

Huffman, D.W., A.J. Sánchez Meador, M.T. Stoddard, J.E. Crouse, and J.P. Roccaforte. 2017. Efficacy of resource objective wildfires for restoring ponderosa pine (Pinus ponderosa) forests of northern Arizona. Forest Ecology and Management 389: 395-403.

Huffman, D.W., T.L. Zegler, and P.Z. Fulé. 2015. Fire history of a mixed conifer forest on the Mogollon Rim, northern Arizona, USA. International Journal Wildland Fire 24: 680-689 https://doi.org/10.1071/WF14005.

Hurteau, M.D., T.A. Robards, D. Stevens, D. Saah, M. North, and G.W. Koch. 2014 Modeling climate and fuel reduction impacts on mixed-conifer forest carbon stocks in the Sierra Nevada, California. Forest Ecology and Management 315: 30-42.

Iniguez, J.M., T.W. Swetnam, and C.H. Baisan. 2009. Spatially and temporally variable fire regime on Rincon Mountain, Arizona, USA. Fire Ecology 5 (1): $3-$ 21 https://doi.org/10.4996/fireecology.0501003.

Kane, J.M., and T.E. Kolb. 2014. Short- and long-term growth characteristics associated with tree mortality in Southwestern mixed-conifer forests. Canadian Journal of Forest Research 44: 1227-1235 https://doi.org/10.1139/cjfr-2014-0186.

Key, C.H., and N.C. Benson. 2006. Landscape assessment: remote sensing of severity, the Normalized Burn Ratio. Pages LA1-LA51. In FIREMON: fire effects monitoring and inventory system, ed. D.C. Lutes. Fort Collins: USDA Forest Service General Technical Report RMRS-GTR-164-CDRocky Mountain Research Station.

Keyser, T.L., L.B. Lentile, F.W. Smith, and W.D. Shepperd. 2008. Changes in forest structure after a large, mixed-severity wildfire in ponderosa pine forests of the Black Hills, South Dakota, USA. Forest Science 54: 328-338.

Laughlin, D.C., P.Z. Fule, D.W. Huffman, J.E. Crouse, and E. Laliberté. 2011. Climatic controls on trait-based forest assembly. Journal of Ecology 99: 1489-1499 https://doi.org/10.1111/j.1365-2745.2011.01885.x.

Lentile, L.B., P. Morgan, A.T. Hudak, M.J. Bobbitt, S.A. Lewis, A.M.S. Smith, and P.R. Robichaud. 2007. Post-fire burn severity and vegetation response following eight large wildfires across the western United States. Fire Ecology 3 (1): 91 108 https://doi.org/10.4996/fireecology.0301091

Margolis, E.Q., and J. Balmat. 2009. Fire history and fire-climate relationships along a fire regime gradient in the Santa Fe Municipal Watershed, NM, USA. Forest Ecology and Management 258: 2416-2430.

Mast, J.N., and J.J. Wolf. 2004. Ecotonal changes and altered tree spatial patterns in lower mixed-conifer forests, Grand Canyon National Park, Arizona, USA. Landscape Ecology 19: 167-180 https://doi.org/10.1023/B:LAND.0000021718.20058.36.

Merriam, C.H. 1890. Results of a biological survey of the San Francisco mountain region and desert of the Little Colorado in Arizona. North America Fauna 3: 1-4.

National Park Service. 2003. Fire monitoring handbook. Boise: US National Park Service, Fire Management Program Center, National Interagency Fire Center.

Ouzts, J., T. Kolb, D. Huffman, and A. Sánchez Meador. 2015. Post-fire ponderosa pine regeneration with and without planting in Arizona and New Mexico. Forest Ecology and Management 354: 281-290.

Puhlick, J.J., D.C. Laughlin, and M.M. Moore. 2013. Factors influencing ponderosa pine regeneration in the southwestern USA. Forest Ecology and Management 264: 10-19

Rehfeldt, G.E., N.L. Crookston, M.V. Warwell, and J.S. Evans. 2006. Empirical analyses of plant-climate relationships for the western United States. International Journal of Plant Sciences 167: 1123-1150.

Rehfeldt, G.E., D.E. Ferguson, and N.L. Crookston. 2009. Aspen, climate, and sudden decline in western USA. Forest Ecology and Management 258: 2353-2364 https://doi.org/10.1086/507711.

Reynolds, R.T., A.J. Sánchez Meador, J.A. Youtz, T. Nicolet, M.S. Matonis, P.L. Jackson, D.G. DeLorenzo, and A.D. Graves. 2013. Restoring composition and structure in Southwestern frequent-fire forests: a science-based framework for improving ecosystem resiliency. Fort Collins: USDA Forest Service General Technical Report RMRS-GTR-310, Rocky Mountains Research Station.

Rodman, K.C., A.J. Sánchez Meador, D.W. Huffman, and K.M. Waring. 2016. Reference conditions and historical fine-scale spatial dynamics in a dry mixed-conifer forest, Arizona, USA. Forest Science 62 (3): 268-280 https://doi.org/10.5849/forsci.15-136.

Salzer, M.W., and K.F. Kipfmueller. 2005. Reconstructed temperature and precipitation on a millennial timescale from tree-rings in southern Colorado Plateau, USA. Climatic Change 70: 465-487 https://doi.org/10.1007/s10584-005-5922-3.

Seager, R., M. Ting, I. Held, Y. Kushnir, L. Lu, G. Vecchi, H.P. Huang, N. Harnik, A. Leetmaa, N.C. Lau, C. Li, J. Velez, and N. Naik. 2007. Model projections of an imminent transition to a more arid climate in southwestern North America. Science 316: 1181-1184 https://doi.org/10.1126/science.1139601.
Stephens, S.L. 2001. Fire history of adjacent Jeffrey pine and upper montane forests in the eastern Sierra Nevada. International Journal Wildland Fire 10: 161-167 https://doi.org/10.1071/WF01008.

Stephens, S.L., B.M. Collins, E. Biber, and P.Z. Fulé. 2016. US federal fire and forest policy: emphasizing resilience in dry forests. Ecosphere 7 (11): 1-19 https:// doi.org/10.1002/ecs2.1584

Stevens-Rumann, C.S., K.B. Kemp, P.E. Higuera, B.J. Harvey, M.T. Rother, D.C. Donato, P. Morgan, and T.T. Veblen. 2018. Evidence for declining forest resilience to wildfires under climate change. Ecology Letters 21: 243-252 https://doi.org/10.1111/ele.12889.

Stoddard, M.T., A.J. Sánchez Meador, P.Z. Fulé, and J.E. Korb. 2015. Five-year postrestoration conditions and simulated climate-change trajectories in a warm/ dry mixed-conifer forest, southwestern Colorado, USA. Forest Ecology and Management 356: 253-261.

Strahan, R.T., A.J. Sánchez Meador, D.W. Huffman, and D.C. Laughlin. 2016. Shifts in community-level traits and functional diversity in a mixed conifer forest: a legacy of land-use change. Journal of Applied Ecology 53 (6): 1755-1765 https://doi.org/10.1111/1365-2664.12737.

Swetnam, T.W., and C.H. Baisan. 1996. Historical fire regime patterns in the southwestern United States since AD 1700. In Proceedings of the second La Mesa Fire symposium, Los Alamos, New Mexico, ed. C.D. Allen, 1-32. Fort Collins: USDA Forest Service General Technical Report RM-GTR-286, Rocky Mountain Forest and Range and Experiment Station.

Tarancón, A.A., P.Z. Fulé, K.L. Shive, C.H. Sieg, A.S. Meador, and B. Strom. 2014 Simulating post-wildfire forest trajectories under alternative climate and management scenarios. Ecological Applications 24: 1626-1637 https://doi.org/ 10.1890/13-1787.1.

Turner, M.G., W.L. Baker, C.J. Peterson, and R.K. Peet. 1998. Factors influencing succession: lessons from large, infrequent natural disturbances. Ecosystems 1: 511-523 https://doi.org/10.1007/s100219900047.

Van Mantgem, P.J., N.J. Stephenson, J.C. Byrne, L.D. Daniels, J.F. Franklin, P.Z. Fulé, M.E. Harmon, A.J. Larson, J.M. Smith, A.H. Taylor, and T.T. Veblen. 2009. Widespread increase of tree mortality rates in the western United States. Science 323: 521-524 https://doi.org/10.1126/science.1165000.

Vines, R.G. 1968. Heat transfer through bark, and the resistance of trees to fire Australian Journal of Botany 16: 499-514 https://doi.org/10.1071/BT9680499.

Waltz, A.E., M.T. Stoddard, E.L. Kalies, J.D. Springer, D.W. Huffman, and A.J. Sánchez Meador. 2014. Effectiveness of fuel reduction treatments: assessing metrics of forest resiliency and wildfire severity after the Wallow Fire, AZ. Forest Ecology and Management 334: 43-52.

Weiss, J.L., C.L. Castro, and J.T. Overpeck. 2009. Distinguishing pronounced droughts in the southwestern United States: seasonality and effects of warmer temperatures. Journal of Climate 22: 5918-5932 https://doi.org/10. 1175/2009JCLI2905.1.

Westerling, A.L., H.G. Hidalgo, D.R. Cayan, and T.W. Swetnam. 2006. Warming and earlier spring increase western US forest wildfire activity. Science 313: 940943 https://doi.org/10.1126/science.1128834.

Westoby, M., D. Falster, A. Moles, P. Vesk, and I. Wright. 2002. Plant ecological strategies: some leading dimensions of variation between species. Annual Review of Ecology and Systematics 33: 125-159 https://doi.org/10.1146/ annurev.ecolsys.33.010802.150452.

Whittaker, R.H., and W.A. Niering. 1975. Vegetation of the Santa Catalina Mountains, Arizona. V. Biomass, production, and diversity along the elevation gradient. Ecology 56: 771-790.

Williams, A.P., C.D. Allen, A.K. Macalady, D. Griffin, C.A. Woodhouse, D.M. Meko, T.W. Swetnam, S.A. Rauscher, R. Seager, H.D. Grissino-Mayer, J.S. Dean, E.R. Cook, C. Gangodagamage, M. Cai, and N.G. McDowell. 2013. Temperature as a potent driver of regional forest drought stress and tree mortality. Nature Climate Change 3: 8-13.

Worrall, J.J., G.E. Rehfeldt, A. Hamann, E.H. Hogg, S.B. Marchetti, M. Michaelian, and L.K. Gray. 2013. Recent declines of Populus tremuloides in North America linked to climate. Forest Ecology and Management 299: 35-51.

Yocom-Kent, L.L., P.Z. Fulé, W.A. Bunn, and E. Gdula. 2015. Historical high-severity fire patches in mixed-conifer forests. Canadian Journal of Forest Research 45: 1587-1596 https://doi.org/10.1139/cjfr-2015-0128.

Zegler, T.J., M.M. Moore, M.L. Fairweather, K.B. Ireland, and P.Z. Fulé. 2012. Populus tremuloides mortality near the southwestern edge of its range. Forest Ecology and Management 282: 196-207. 